\title{
Atrial Natriuretic Peptide Receptor 1
}

National Cancer Institute

\section{Source}

National Cancer Institute. Atrial Natriuretic Peptide Receptor 1. NCI Thesaurus. Code C112515.

Atrial natriuretic peptide receptor 1 (1061 aa, $\sim 119 \mathrm{kDa}$ ) is encoded by the human NPR1 gene. This protein plays a role in both guanylate cyclase activity and natriuretic peptide binding. 